\title{
POLA ADAPTASI NELAYAN TERHADAP PERUBAHAN IKLIM: Studi Kasus Nelayan Dusun Ciawitali, Desa Pamotan, Kecamatan Kalipucang, Kabupaten Ciamis, Jawa Barat
}

\section{Adaptation Pattern of Fishers in Addressing Climate Change: A Case Study of Fishers in Ciawitali, Pamotan Village, Province Kalipucang Subdistrict, Ciamis Regency of West Java}

\author{
Ratna Patriana ${ }^{1}$ dan Arif Satria ${ }^{2}$ \\ ${ }^{1}$ Center for Climate Risk and Opportunity Management in Southeast Asia and Pacific, \\ Institut Pertanian Bogor, Bogor 16183, Indonesia. Telp: (0251)8313709, Fax: (0251)8310779 \\ ${ }^{2}$ Fakultas Ekologi Manusia, Institut Pertanian Bogor \\ JI. Kamper, Kampus IPB Dramaga, Bogor 16680, Indonesia. Telp./Fax: (0251)8629227
}

Diterima 2 November 2012 - Disetujui 4 Juni 2013

\begin{abstract}
ABSTRAK
Tujuan dari penelitian ini adalah (1) mengidentifikasi dampak perubahan iklim pada aktivitas nelayan perikanan tangkap, dan (2) menganalisis pola adaptasi dan strategi ekonomi yang dilakukan oleh nelayan untuk mengatasi dampak ekonomi yang ditimbulkan oleh perubahan iklim. Penelitian dilakukan dengan menggunakan metode kualitatif eksploratif yang dilengkapi dengan studi literatur. Pengambilan data primer dilakukan melalui wawancara mendalam, observasi, dan Focused Group Discussion (FGD). Hasil penelitian menunjukkan bahwa (1) perubahan iklim menyebabkan terjadinya perubahan wilayah dan musim penangkapan ikan, meningkatnya resiko melaut akibat gelombang ekstrim dan angin kencang, dan menghambat akses nelayan dalam melaut akibat pendangkalan muara sungai dan gelombang besar, (2) adaptasi yang dilakukan oleh nelayan antara lain adalah adaptasi iklim melalui "mengejar musim ikan", adaptasi sumber daya pesisir, adaptasi alokasi sumber daya dalam rumah tangga yang meliputi optimalisasi tenaga kerja dalam rumah tangga dan pola nafkah ganda, dan keluar dari kegiatan perikanan (escaping from fisheries).
\end{abstract}

Kata Kunci: perubahan iklim, nelayan, adaptasi, mata pencaharian

\begin{abstract}
The objectives of this research were (1) to identify the impact of climate change on fishing activities and; (2) to analyze the adaptation patterns and economic strategy undertaken by fishers to overcome the economic impact caused by climate change. The study was conducted using qualitative exploratory methods, complemented with literature study. Primary data were collected through in-depth interview, observation, and focused group discussion (FGD). The results showed that; (1) climate change leads to changes in the fishing area and the fishing season, the increased risk in fishing activity due to extreme waves and strong winds, and disrupt access to fishing due to siltation of the estuary and large waves and; (2) fishers undertake economy strategies and climate change adaptations in terms of climate adaptation through "chasing the fishing season", coastal resources adaptation, resource allocation within households including optimalization of labor in the family, multiple livelihood and escaping from fisheries.
\end{abstract}

Keywords: climate change, fisher, adaptation, livelihood 


\section{PENDAHULUAN}

Indonesia sebagai negara kepulauan tropis memiliki kekayaan hayati laut yang sangat luar biasa dan merupakan potensi besar bagi kemakmuran rakyatnya. Nelayan dengan ikatan ekonomi maupun historisnya telah memanfaatkan sumber daya hayati laut ini secara turun temurun. Namun kondisi saat ini menunjukkan bahwa berada di tengah melimpahnya kekayaan sumber daya alam hayati laut dan pesisir ternyata belum dapat membuat perekonomian nelayan Indonesia terangkat dari garis kemiskinan.

Keterpurukan nelayan ini diperparah oleh kerusakan ekologi yang terjadi pada ekosistem pesisir dan laut yang menjadi sumber matapencahariannya. Salah satu faktor penyebab terjadinya perubahan ekologi pesisir dan laut ini adalah perubahan iklim. Perubahan iklim mengacu pada perubahan-perubahan yang terjadi pada iklim dari waktu ke waktu baik secara alamiah maupun disebabkan oleh aktivitas manusia (IPCC, 2007). Dampak yang ditimbulkan oleh perubahan iklim yaitu terjadinya kenaikan muka air laut (Murdiyarso, 2007; IPCC, 2007; Tebtebba, 2008; Satria, 2009; UNEP, 2009), peningkatan suhu air laut (IPCC, 2007; Chen, 2008; Satria, 2009; UNEP, 2009), meningkatnya keasaman laut (Chen, 2008; UNEP, 2009), perubahan pola sirkulasi dan proses upwelling di lautan (Diposaptono et al., 2009;UNEP, 2009), perubahan curah hujan (Murdiyarso, 2007), serta meningkatnya frekuensi dan intensitas cuaca ekstrim (IPCC, 2007).

Setidaknya terdapat empat hal yang dapat terjadi pada perikanan tangkap terkait dampakdampakperubahan iklim di wilayah laut, berdasarkan pendapat (Diposaptono et al., 2009). Pertama, terjadi perubahan pola migrasi ikan akibat perubahan suhu permukaan laut. Kedua, terjadi stratifikasi kolom air yang memengaruhi proses upwelling yang berkorelasi positif dengan gerombolan ikan (fish schooling), dan dengan sendirinya mengakibatkan nelayan sulit menangkap ikan. Ketiga, terjadi perubahan kawasan penangkapan ikan (fishing ground). Keempat, semakin terpuruknya nasib nelayan akibat dibutuhkannya waktu dan biaya yang lebih besar untuk melaut karena migrasi maupun rusaknya habitat perikanan dan fishing ground.

IPCC (2007) juga menyebutkan dampak perubahan iklim berupa pemutihan terumbu karang (coral bleaching) yang berperan sebagai ekosistem penyangga habitat ikan dan biota laut yang selama ini merupakan komoditas tangkapan nelayan. Supriharyono (2007) menyebutkan sejumlah organisme bernilai ekonomi yang kehidupannya bergantung pada terumbu karang, yaitu penyu, udang barong, octopus, conches, kerang, oyster, rumput laut, kima dan teripang. Kerusakan yang terjadi pada ekosistem terumbu karang pada akhirnya memengaruhi populasi ikan dan dapat berimplikasi pada aktivitas melaut dan perekonomian para nelayan (Satria, 2009).

Sejumlah permasalahan perubahan iklim yang berdampak pada kegiatan perikanan tangkap, sebagaimana telah dipaparkan sebelumnya, merupakan landasan akan pentingnya dilakukan suatu penelitian yang bertujuan untuk (1) mengidentifikasi dampak perubahan iklim pada aktivitas perikanan tangkap, dan (2) menganalisis pola adaptasi dan strategi ekonomi yang dilakukan oleh nelayan untuk mengatasi dampak ekonomi yang ditimbulkan oleh perubahan iklim.

\section{METODOLOGI}

\section{Lokasi dan Waktu}

Penelitian ini dilakukan sejak bulan Juni 2010 hingga September 2010 di Dusun Ciawitali, Desa Pamotan, Kecamatan Kalipucang, Kabupaten Ciamis, Provinsi Jawa Barat. Penentuan lokasi penelitian dilakukan secara purposive (sengaja) dengan pertimbangan bahwa Dusun Ciawitali merupakan kampung nelayan yang didominasi oleh nelayan tradisional, sementara tantangan yang dihadapi cukup besar mengingat kondisi lautan yang bertemu langsung dengan Samudra Hindia. Selain itu, Desa Pamotan juga merupakan lokasi penelitian mengenai dampak perubahan iklim yang dilakukan oleh Center for Climate Risk and Opportunity Management in Southeast Asia and Pacific (CCROM SEAP) Institut Pertanian Bogor, bekerjasama dengan Ikatan Petani Pengendalian Hama Terpadu Indonesia (IPPHTI) dan Diakonie Katastrophenhilfe Germany.

Nelayan Ciawitali merupakan representasi dari nelayan yang dianggap rentan terkena dampak perubahan iklim meliputi perubahan pola angin. Di samping itu, salah satu komoditas tangkapan yang diandalkan oleh nelayan Ciawitali adalah udang karang (lobster), dimana ekosistem terumbu karang yang menjadi habitatnya juga mengalami tekanan ekologis akibat terjadinya perubahan iklim. 


\section{Teknik Pemilihan Informan}

Populasi dari penelitian ini adalah nelayan di Dusun Ciawitali yang melakukan kegiatan penangkapan di lautan dan bukanlah di sekitar muara Sungai Citanduy ataupun Segara Anakan. Populasi diambil berdasarkan informasi yang diperoleh dari data Rukun Nelayan (RN) dan Kelompok Usaha Bersama (KUB) Putra Kendal Ciawitali. Dari data tersebut diketahui jumlah populasi nelayan Ciawitali sebanyak 90 orang. Informan kunci dalam penelitian ini ditentukan sebanyak 8 (delapan) orang yang terdiri dari 1 (satu) orang kepala RN Ciawitali, 1 (satu) orang kepala KUB Putra Kendal Ciawitali, dan 6 (enam) orang tokoh nelayan yang telah melakukan penangkapan lebih dari 15 tahun. Namun begitu, wawancara juga dilakukan terhadap sebanyak mungkin nelayan sehingga dapat mencapai titik jenuh informasi, dimana tambahan informan tidak lagi menghasilkan pengetahuan baru.

\section{Jenis, Sumber, dan Teknik Pengumpulan Data}

Jenis data yang digunakan dalam penelitian ini terdiri dari data primer dan data sekunder. Pengumpulan data primer dilakukan melalui wawancara mendalam (in-depth interview), observasi atau pengamatan berperan serta dan diskusi kelompok terarah atau Focused Group Discussion (FGD). Pengumpulan data sekunder dilakukan melalui studi literatur serta kajian dokumen-dokumen yang relevan dengan tujuan penelitian. Kebutuhan data, metode pengumpulan, jenis dan sumber data dalam penelitian ini dapat dilihat dalam Tabel 1.

Tabel 1. Kebutuhan Data, Metode Pengumpulan Data, Jenis, dan Sumber Data.

Table 1. Required Data, Data Collection Methods, Types and Source of Data.

\begin{tabular}{|c|c|c|c|c|}
\hline No. & $\begin{array}{l}\text { Kebutuhan Data / } \\
\text { Required Data }\end{array}$ & $\begin{array}{l}\text { Metode Pengumpulan } \\
\text { Data / Data Collection } \\
\text { Methods }\end{array}$ & $\begin{array}{l}\text { Jenis Datal } \\
\text { Types of Data }\end{array}$ & $\begin{array}{l}\text { Sumber Data / } \\
\text { Source of Data }\end{array}$ \\
\hline 1 & $\begin{array}{l}\text { Kondisi sosial-ekonomi nelayan / } \\
\text { Socio-economic condition of the } \\
\text { fishers }\end{array}$ & $\begin{array}{l}\text { Wawancara, Observasi / } \\
\text { Interview, Observation }\end{array}$ & $\begin{array}{l}\text { Primer / } \\
\text { Primary }\end{array}$ & $\begin{array}{l}\text { Nelayan, Tokoh } \\
\text { Masyarakat, dan Literatur } \\
\text { / Fishers, Community } \\
\text { Leaders, and Literature }\end{array}$ \\
\hline 2 & $\begin{array}{l}\text { Kondisi ekosistem dan gejala } \\
\text { perubahan iklim yang terjadi / } \\
\text { Ecosystem condition and the } \\
\text { current climate change symptoms }\end{array}$ & $\begin{array}{l}\text { Wawancara, Observasi / } \\
\text { Interview, Observation }\end{array}$ & $\begin{array}{l}\text { Primer / } \\
\text { Primary }\end{array}$ & Nelayan / Fishers \\
\hline 3 & $\begin{array}{l}\text { Dampak ekologis dari perubahan } \\
\text { iklim yang mempengaruhi } \\
\text { kegiatan penangkapan ikan / } \\
\text { Ecological impact of climate } \\
\text { change which affects the } \\
\text { fisheries activity }\end{array}$ & $\begin{array}{l}\text { Studi Literatur, } \\
\text { Wawancara, Observasi } \\
\text { / Literature Study, } \\
\text { Interview, Observation }\end{array}$ & $\begin{array}{l}\text { Primer, } \\
\text { Sekunder } \\
\text { / Primary, } \\
\text { Secondary }\end{array}$ & Nelayan / Fishers \\
\hline 4 & $\begin{array}{l}\text { Pengaruh perubahan ekologi laut } \\
\text { terhadap perekonomian nelayan } \\
\text { / Impact of marine ecological } \\
\text { change to fishers economy }\end{array}$ & $\begin{array}{l}\text { Studi Literatur, } \\
\text { Wawancara, Observasi } \\
\text { / Literature Study, } \\
\text { Interview, Observation }\end{array}$ & $\begin{array}{l}\text { Primer, } \\
\text { Sekunder } \\
\text { / Primary, } \\
\text { Secondary }\end{array}$ & $\begin{array}{l}\text { Nelayan dan Koperasi } \\
\text { Nelayan / Fishers and } \\
\text { Fisher's Cooperative }\end{array}$ \\
\hline 5 & $\begin{array}{l}\text { Kegiatan penangkapan ikan } \\
\text { sebelum dan sesudah terjadinya } \\
\text { perubahan ekologi laut akibat } \\
\text { perubahan iklim / Fishing } \\
\text { activities before and after the } \\
\text { ecological changes of the ocean } \\
\text { due to climate change }\end{array}$ & $\begin{array}{l}\text { Wawancara, Observasi } \\
\text { / Interview, Observation }\end{array}$ & $\begin{array}{l}\text { Primer / } \\
\text { Primary }\end{array}$ & Nelayan / Fishers \\
\hline 6 & $\begin{array}{l}\text { Wilayah tangkapan / Fishing } \\
\text { groud }\end{array}$ & $\begin{array}{l}\text { Observasi, FGD / } \\
\text { Observation, Focused } \\
\text { Group Discussion }\end{array}$ & $\begin{array}{l}\text { Primer / } \\
\text { Primary }\end{array}$ & Nelayan / Fishers \\
\hline 7 & $\begin{array}{l}\text { Musim penangkapan ikan / } \\
\text { Fishing season }\end{array}$ & $\begin{array}{l}\text { FGD / Focused Group } \\
\text { Discussion }\end{array}$ & $\begin{array}{l}\text { Primer / } \\
\text { Primary }\end{array}$ & Nelayan / Fishers \\
\hline 8 & $\begin{array}{l}\text { Adaptasi perikanan tangkap / } \\
\text { Capture fisheries adaptation }\end{array}$ & $\begin{array}{l}\text { Wawancara, Observasi / } \\
\text { Interview, Observation }\end{array}$ & $\begin{array}{l}\text { Primer / } \\
\text { Primary }\end{array}$ & Nelayan / Fishers \\
\hline 9 & $\begin{array}{l}\text { Strategi ekonomi dan mata } \\
\text { pencaharian nelayan / Economic } \\
\text { and livelihood strategy of the } \\
\text { fishers }\end{array}$ & $\begin{array}{l}\text { Wawancara, Observasi / } \\
\text { Interview, Observation }\end{array}$ & $\begin{array}{l}\text { Primer / } \\
\text { Primary }\end{array}$ & $\begin{array}{l}\text { Nelayan dan Tokoh } \\
\text { Masyarakat / Fishers and } \\
\text { Community Leaders }\end{array}$ \\
\hline
\end{tabular}




\section{Metode Analisis Data}

Teknik analisis data kualitatif dalam penelitian ini mengacu pada konsep Miles dan Huberman (1984, 1994 dalam Miles dan Huberman, 2009) dimana terdapat tiga sub-proses analisis data yang saling terkait, yaitu reduksi data, penyajian data dan pengambilan kesimpulan. Reduksi data merupakan proses pemilihan, pemusatan perhatian pada penyederhanaan, pengabstrakan, dan transformasi data kasar yang muncul dari catatan-catatan tertulis dilapangan. Penyajian data merupakan penyusunan informasi yang memungkinkan adanya penarikan kesimpulan dan pengambilan tindakan. Sedangkan penarikan kesimpulan berbentuk pencatatan keteraturan pola-pola yang terjadi, penjelasan, konfigurasi-konfigurasi yang mungkin, alur sebabakibat, dan proposisi. Ketiga kegiatan analisis dan pengumpulan data ini merupakan proses siklus dan interaktif sebagaimana ditunjukkan dalam Gambar 1. Analisis data dilakukan secara berlanjut, berulang dan terus menerus.

\section{HASIL DAN PEMBAHASAN}

\section{Dampak Ekologis}

Berdasarkan perspektif nelayan Ciawitali, perubahan ekologi pada ekosistem laut memengaruhi aktivitas penangkapan ikan melalui terjadinya perubahan musim ikan dan kekacauan musim angin.

\section{1) Perubahan musim ikan}

IPCC (2001) dalam (IPCC), 2007) menyebutkan bahwa kedepannya, perubahan arus laut, naiknya permukaan laut, suhu air laut, perubahan salinitas, arah dan kecepatan angin, kekuatan upwelling, ketebalan lapisan pencampuran di laut dan respon predator terhadap perubahan iklim memiliki potensi untuk secara substansial mengubah habitat berkembang biak ikan dan pasokan makanan bagi ikan hingga akhirnya kelimpahan populasi ikan di perairan Asia.

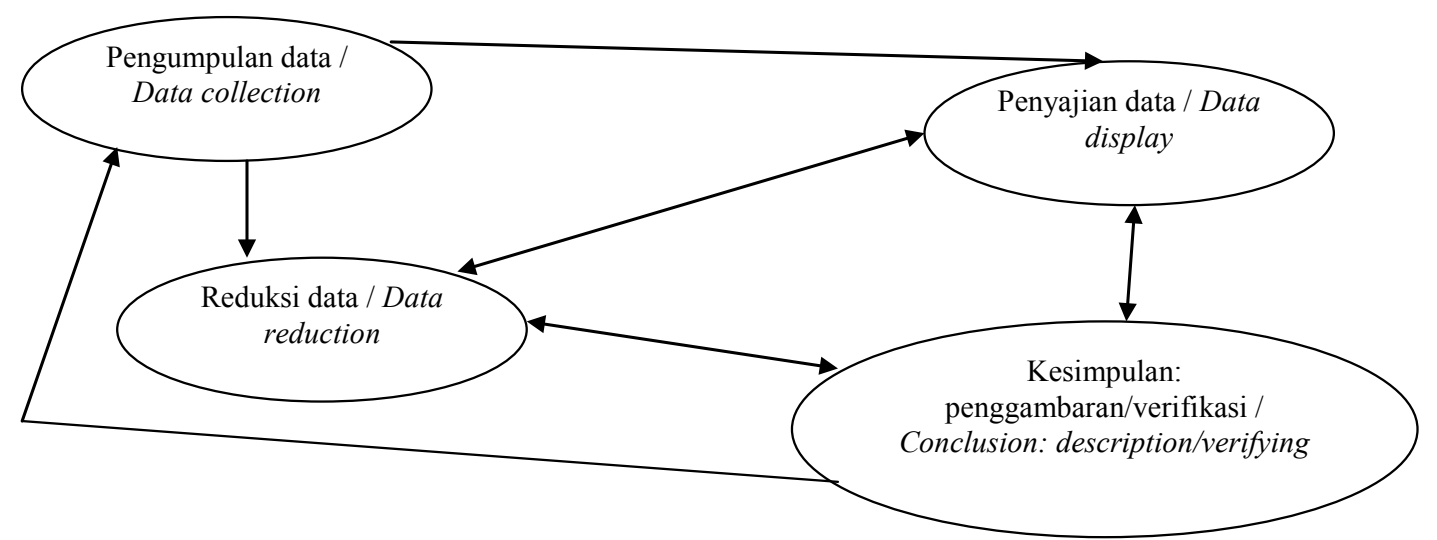

Gambar 1. Komponen Analisis Data: Model Interaktif.

Figure 1. Components of Data Analysis: Interactive Model.

Sumber: Miles dan Huberman (1984, 1994 dalam Miles dan Huberman, 2009)/

Source: Miles and Huberman (1984, 1994 in Miles and Huberman, 2009)

Untuk mengurangi kemungkinan terjadinya kasalahan interpretasi digunakan pula metode triangulasi. Teknik ini mengacu pada suatu proses pemanfaatan persepsi yang beragam untuk mengklarifikasi makna, memverifikasi kemungkinan pengulangan dari suatu observasi ataupun interpretasi, namun harus dengan prinsip bahwa tidak ada observasi atau interpretasi yang seratus persen dapat diulang (Stake, 2009). Teknik triangulasi ini berguna untuk memperoleh kombinasi data yang akurat melalui uji keabsahan dengan uji silang tiga sumber data, yaitu hasil wawancara, observasi serta studi literatur.
Perubahan iklim menyebabkan terjadinya perubahan suhu permukaan laut dan stratifikasi kolom air yang kemudian memengaruhi proses upwelling di lautan (Diposaptono et al., 2009). Perubahan sirkulasi laut, dan proses upwelling ini menyebabkan terjadinya perubahan pola migrasi ikan dan gerombolan ikan (Diposaptono et al., 2009). Hal ini juga sejalan dengan pendapat seorang ahli ekologi, Eugene P. Odum (1994) yang menyatakan bahwa bagian lautan yang paling produktif adalah di tempat terjadinya penaikan air atau upwelling ini. Migrasi ikan, dimana gerombolan ikan-ikan dengan jenis tertentu melintasi suatu 
Dampak Perubahan Iklim di Wilayah Pesisir dan Laut $/$ Impact of Climate Change on Coastal and Marine

- Kenaikan permukaan air laut/Sea level rise

Perubahan pola angin/

Changes in wind patterns

- Perubahan pola hidrologi/

Changes in hydrologic patterns

- Kenaikan suhu air laut/

Rise in sea water temperature

- Kenaikan $\mathrm{pH}$ air laut/

The increase in the $\mathrm{pH}$ of sea water

Kerusakan Ekologi:/Ecological damage:

- Intrusi air laut ke daratan/Salt-water intrusion

- Gelombang ekstrim dan badai/Extreme waves and storm

- Genangan dan banjir/Inundation and flooding

- Erosi pantai/Coastal erosion

- Kerusakan terumbu karang/Damage to coral reefs

- Perubahan proses upwelling, gerombolan ikan/ Changes in upwelling process, schools of fish

- Perubahan pola migrasi ikan/

Changes in the migration patterns of fish

- Perubahan morfologi pantai dan mangrove/ Changes in coastal morphology and mangrove

- Meningkatnya salinitas air, kerusakan lahan budidaya perikanan dan sumber-sumber air tawar/Increasing water salinity, land degradation and aquaculture freshwater sources

- Meningkatnya frekuensi dan intensitas badai di lautan/Increased frequency and intensity of storms at sea

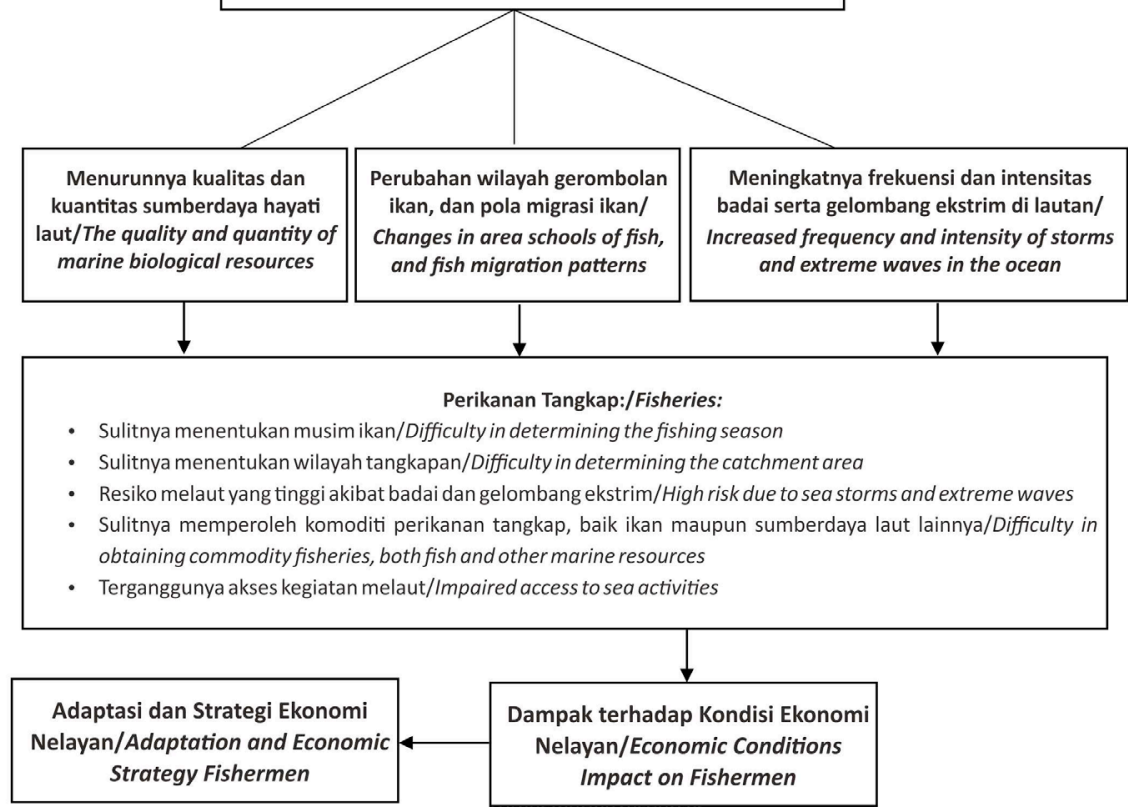

Gambar 2. Kerangka Pendekatan.

Figure 2. Framework Approach.

Sumber: Data sekunder diolah (2010) / Source: Secondary data, processed (2010)

wilayah penangkapan inilah yang dipahami oleh nelayan sebagai musim penangkapan ikan atau musim ikan.

Perubahan musim ikan ini sangat mempengaruhi penghasilan nelayan mengingat beberapa spesies ikan memang hanya datang di musim-musim tertentu. Salah satunya adalah ikan layur. Ikan layur merupakan salah satu ikan musiman yang hanya bisa ditangkap pada periode tertentu dalam satu tahun. Biasanya ketika musim ikan layur datang, ikan ini akan muncul dalam jumlah yang besar. Menurut nelayan, perubahan iklim diduga telah memberi dampak yang signifikan terhadap periode musim ikan jenis ini, karena berdasarkan pengakuan nelayan, pada beberapa tahun belakangan jumlah ikan layur yang diperoleh semakin sedikit atapun tidak terdapat ikan layur sama sekali dalam satu tahun.

\section{2) Kekacauan musim angin}

Salah bentuk dari perubahan iklim yang mepengaruhi kegiatan produksi nelayan adalah perubahan pola angin (UNEP, 2009). Perubahan pola angin, selain memengaruhi proses sirkulasi yang pada akhirnya berdampak pada kelimpahan ikan di lautan, juga menyebabkan sulitnya nelayan memprediksi waktu-waktu yang tepat untuk melaut. 
Nelayan Ciawitali mengenal dua musim angin yang berhembus di wilayah perairan Ciawitali, yaitu musim angin timur dan musim angin barat. Musim angin timur berhembus sejak bulan April hingga Agustus, sedangkan musim angin barat berhembus di bulan September hingga Januari. Pengalaman nelayan Ciawitali dalam mencari ikan selama bertahun-tahun telah menghasilkan kalender musim aktivitas nelayan sebagaimana dapat dilihat dalam gambar 3 berikut.
Nelayan Ciawitali memanfaatkan musim angin timur sebagai momentum untuk mencari ikan. Sedangkan berhembusnya angin barat merupakan suatu hambatan yang menyebabkan nelayan tidak dapat melaut di sekitar wilayah tangkapan ikan seperti biasanya. Hal ini berkaitan dengan wilayah penangkapan ikan nelayan Ciawitali yang terlindung dari terpaan angin timur namun sangat rentan akan terpaan angin barat. Wilayah penangkapan ikan nelayan ini dapat dilihat dalam Gambar 4.

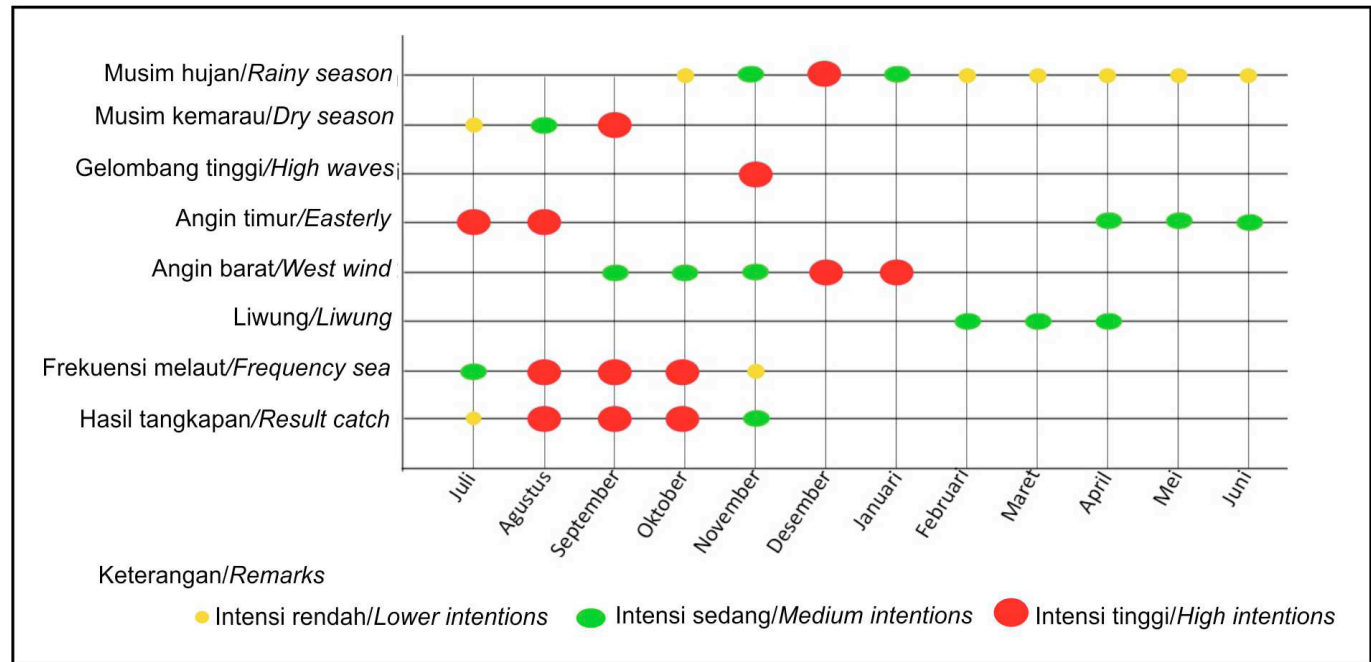

Gambar 3. Kalender Musim Penangkapan Ikan Nelayan Ciawitali Sebelum Terjadi Perubahan Iklim (lebih dari 10 tahun yang lalu).

Figure 3. Fishing Season Calendar of Ciawitali's Fishers Before The Occurance of Climate Change (over 10 years ago).

Sumber: Data pimer diolah (2010) / Source: Primary data, processed (2010)

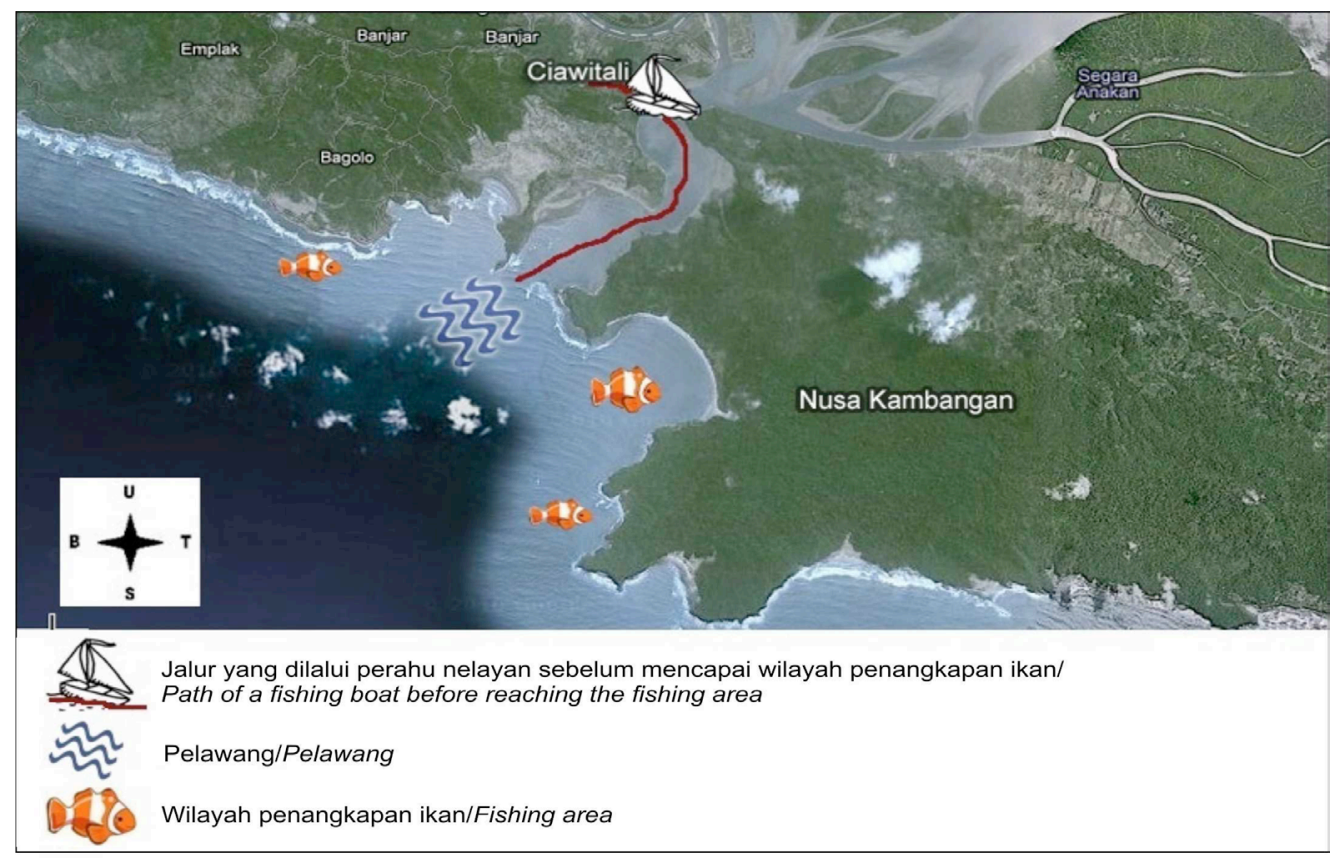

Gambar 4. Wilayah Penangkapan Ikan Nelayan Ciawitali.

Figure 4. Fishing Ground of Ciawitali's Fishers.

Sumber: Data pimer diolah (2010) / Source: Primary data, processed (2010) 
Dalam FGD yang dilakukan bersama nelayan Ciawitali, nelayan mengungkapkan bahwa kondisi musim angin yang tidak menentu menyebabkan sulitnya menyusun kalender musim yang menggambarkan kondisi ekologis laut dan aktivitas perikanan di masa sekarang. Perubahan iklim, berdasarkan perspektif nelayan, menyebabkan kekacauan musim angin di wilayah penangkapan. Bulan-bulan yang telah dipahami sebagai musim berhembusnya angin timur, saat ini mengalami pergeseran atau kekacauan dimana angin barat kadang datang secara tiba-tiba di tengah musim angin timur. Selain itu, pergeseran musim terjadi dimana angin barat datang lebih awal, yang sekaligus memotong masa angin timur dan merugikan sebagian besar nelayan yang tidak dapat pergi melaut. Kekacauan musim ini menyebabkan sulitnya nelayan menentukan waktu yang tepat untuk melaut. Persepsi nelayan akan terjadinya kekacauan musim angin dapat disimak dalam kutipan wawancara dengan salah satu tokoh nelayan, AR (50 th) sebagai berikut:

"Sejak dahulu, di bulan JuliAgustus, tangkapan yang kita peroleh biasanya banyak, karena bulan-bulan ini musimnya angin timur. Jadi lebih aman untuk ke laut. Tapi beberapa tahun terakhir di musim angin timur terkadang terjadi angin barat juga. Contohnya saja bulan Juli kemarin. Saya sempat terjebak selama berjam-jam di Nusa Kambangan, karena angin barat yang tiba-tiba datang dan berlangsung hampir seharian"

\section{Dampak Perubahan Iklim}

Menurut nelayan, dengan didukung oleh literatur, perubahan iklim menyebabkan terjadinya dampak sosial-ekonomi pada: (1) kesehatan lingkungan dan pemukiman masyarakat; dan (2) aktivitas perikanan tangkap, akibat sulitnya menentukan wilayah tangkapan ikan, sulitnya menentukan musim penangkapan ikan, meningkatnya resiko melaut, dan terganggunya akses kegiatan melaut ${ }^{1}$.

1. Dampak pada kesehatan lingkungan dan pemukiman masyarakat. Dampak perubahan iklim yang terjadi pada lingkungan masyarakat Ciawitali yaitu terganggunya sumber-sumber air bersih dan terjadinya angin puting beliung di wilayah pemukiman. Kondisi tanah di perkampungan nelayan Ciawitali sendiri didominasi oleh tanah berkapur (karst). Jika musim kemarau tiba, kuantitas air akan menurun. $\mathrm{Di}$ beberapa wilayah terjadi kekeringan, sedangkan beberapa tempat lainnya terdapat air dengan kualitas yang baik. Sedangkan jika musim hujan berkepanjangan, jumlah air akan melimpah, namun kualitasnya menurun. Air yang dihasilkan berwarna putih susu dengan kandungan kapur yang tinggi. Dampak lain dari perubahan iklim ini adalah meningkatnya cuaca ekstrim yang berpotensi membahayakan kehidupan penduduk pesisir. Nelayan menduga hal ini juga merupakan penyebab terjadinya angin puting beliung yang menimpa pemukiman masyarakat Ciawitali pada tahun 2009.

2. Dampak pada aktivitas perikanan tangkap. Pada perikanan, perubahan iklim menyebabkan menurunnya hasil tangkapan nelayan yang dipicu oleh:

\section{a). Sulitnya menentukan wilayah tangkapan ikan.}

Nelayan Ciawitali telah memiliki wilayah penangkapan tertentu yang menjadi areanya mencari ikan selama bertahun-tahun. Perubahan iklim yang menyebabkan perubahan pola migrasi ikan terjadi pula di wilayah perairan Ciawitali. Hal ini kemudian menimbulkan kendala di kalangan nelayan tradisional yang masih mengandalkan pengetahuan lokal serta pengalaman empirik semata dalam pencarian ikan. Ketika perubahan iklim memberi dampak yang signifikan pada kondisi ekosistem laut dan membuat banyak perbedaan dibanding kondisi lautan sebelumnya, pengalaman empirik nelayan dalam pencarian ikan menjadi tidak berlaku lagi. Nelayan menjadi sulit untuk menentukan wilayah penangkapan

\footnotetext{
Dampak-dampak perubahan iklim ini dirangkum dari hasil FGD dan wawancara mendalam yang dilakukan bersama nelayan Ciawitali, didukung oleh literatur dan observasi peneliti (metode triangulasi).
} 
ikan. Hal ini diperburuk dengan semakin sedikitnya stok ikan yang terdapat di lautan, baik akibat perubahan pola migrasi ikan maupun kerusakan wilayah mangrove yang merupakan habitat dari berbagai jenis komoditas tangkapan nelayan.

b). Sulitnya menentukan musim penangkapan ikan.

Perubahan iklimyang menyebabkan tidak lagi berlakunya kalender musim penangkapan ikan, menyebabkan nelayan merasa kesulitan dalam menentukan waktu-waktu untuk memulai kegiatan melaut. Berbagai pengetahuan lokal, seperti tata mangsa juga dirasakan oleh nelayan tidak lagi relevan sebagai acuan dalam menghitung musim angin. Sulitnya memprediksi musim penangkapan ikan ini juga menyebabkan kerugian yang signifikan bagi para nelayan. Hal tersebut terjadi ketika tiba periode dimana biasanya nelayan melaut dan mendapatkan hasil tangkapan yang menguntungkan, namun yang terjadi justru biaya produksi yang dikeluarkan melebihi dari hasil yang diperoleh.

c). Meningkatnya resiko melaut.

Salah satu dampak perubahan iklim pada eksosistem laut adalah meningkatnya frekuensi gelombang ekstrim dan badai. Hal ini juga merupakan dampak turunan dari terjadinya kenaikan permukaan air laut (UNEP, 2009). Pada wilayah perairan Ciawitali gelombang ekstrim serta badai merupakan ancaman yang biasanya datang ketika tiba musim angin barat serta musim penghujan. Namun perubahan iklim yang terjadi menyebabkan kejadian gelombang ekstrim dan angin kencang juga seringkali terjadi di musim angin timur, dan masa-masa puncak kegiatan penangkapan. Hal ini tentu sangat merugikan, dimana perahu dan sarana penangkapan ikan nelayan Ciawitali masih tradisional dan belum dalam kapasitas menghadapi badai ataupun gelombang besar.

d). Terganggunya akses kegiatan melaut.

Terdapat dua dampak perubahan iklim yang menyebabkan terganggunya akses melaut para nelayan, yaitu gelombang besar dan pendangkalan muara sungai. Pertama, gelombang besar. Padagambar 3 dapat dilihat bahwa pelawangan merupakan pintu keluar yang digunakan nelayan dalam mencapai lautan lepas. Pelawangan ini merupakan gugus bebatuan dan karang dengan sebuah celah yang dapat dilewati oleh perahu. Jika terjadi gelombang besar nelayan tidak mampu melewati celah ini, dengan kata lain kegiatan melaut tidak dapat dilakukan karena perahu yang digunakan tidak dapat menjangkau lautan. Kedua, pendangkalan di muara sungai. Sebagaimana diungkapkan dalam Diposaptono, et al., (2009) kenaikan muka air laut menyebabkan perubahan pola sedimentasi dan pendangkalan di muara sungai yang dapat mengganggu akses keluar masuknya perahu yang digunakan nelayan untuk melaut. Ciawitali merupakan wilayah yang terkena dampak yang signifikan akibat sedimentasi muara sungai Citanduy dan menyebabkan pendangkalan pada aliran sungai yang merupakan akses keluar-masuknya perahu nelayan Ciawitali dalam kegiatan penangkapan. Hal ini diperburuk dengan adanya perubahan iklim. Terjadinya sedimentasi di jalur keluar-masuknya perahu nelayan ini sangat menyulitkan nelayan karena pada saat-saat air surut, nelayan bahkan tidak dapat melewati aliran tersebut dan harus memaksakan untuk mendorong perahunya sejauh lebih dari satu kilometer untuk dapat pergi melaut.

Berbagai gejala perubahan iklim di wilayah pesisir yang dipicu oleh kenaikan permukaan air laut, perubahan suhu dan keasaman laut, meningkatnya frekuensi dan intensitas cuaca ekstrim, serta perubahan curah hujan merupakan sederetan faktor yang memicu terjadinya berbagai perubahan fisik dan lingkungan yang berdampak pada kegiatan produksi dan kehidupan nelayan Ciawitali. Perubahan fisik seperti kerusakan ekosistem terumbu karang, sedimentasi di muara sungai dan sebagainya memicu perbagai perubahan lain yang pada akhirnya berdampak pada kondisi sosial dan ekonomi nelayan sebagaimana dipaparkan sebelumnya. Pengaruh-pengaruh ini secara umum dilihat dalam Gambar 5. 


\section{Adaptasi terhadap Perubahan Iklim dan Strategi Ekonomi Nelayan}

\section{Adaptasi Iklim}

Sulitnya memperoleh hasil tangkapan di suatu wilayah penangkapan ikan mendorong para nelayan Ciawitali melakukan strategi adaptasi yang di kalangan nelayan biasa disebut dengan "strategi mengejar musim ikan". Strategi ini merupakan bentuk adaptasi yang dilakukan oleh nelayan Ciawitali apabila di wilayah perairan sekitar Ciawitali mengalami masa paceklik. Informasi keberadaan ikan di wilayah lain dari satu nelayan ke nelayan lainnya inilah yang mendorong para nelayan melakukan kegiatan penangkapan ikan di wilayah dimana musim ikan tersebut terjadi. Salah satu tokoh nelayan, JA (38 tahun) menyebutkan:

“....kalau di Pacitan sedang musim ikan dan disini tidak, kita mengejar musim sampai kesana, perahu diangkut. Sampai ke wilayah ujung kulon juga pernah. Kadang musim ikan sulit ditebak. Di sini susah sekali mendapatkan ikan, namun di lokasi lain bisa saja ikan-ikan sangat melimpah."

\section{2). Adaptasi Sumber daya Pesisir}

Adaptasi sumber daya pesisir adalah bentuk strategi ekonomi melalui pemanfaatan sumber daya pesisir untuk menghasilkan berbagai komoditas bernilai ekonomi tanpa pergi ke laut lepas. Salah satu sumber daya yang cukup potensial adalah mangrove. Dusun Ciawitali memiliki lahan mangrove yang cukup luas. Walaupun bukan dalam kondisi yang sangat baik, perairan di wilayah mangrove ini masih memberikan hasil perikanan yang bermanfaat bagi para nelayan. Salah satu komoditas wilayah mangrove dengan nilai ekonomi yang tinggi adalah kepiting bakau. Kegiatan pencarian kepiting bakau ini juga menjadi salah satu alternatif pola adaptasi yang dilakukan oleh nelayan Ciawitali di kala kondisi cuaca tidak memungkinkan untuk ke laut. Di musim-musim paceklik pun banyak nelayan yang mencari kepiting bakau sebagai komoditas substitusi untuk menutupi kebutuhan hidup seharihari.

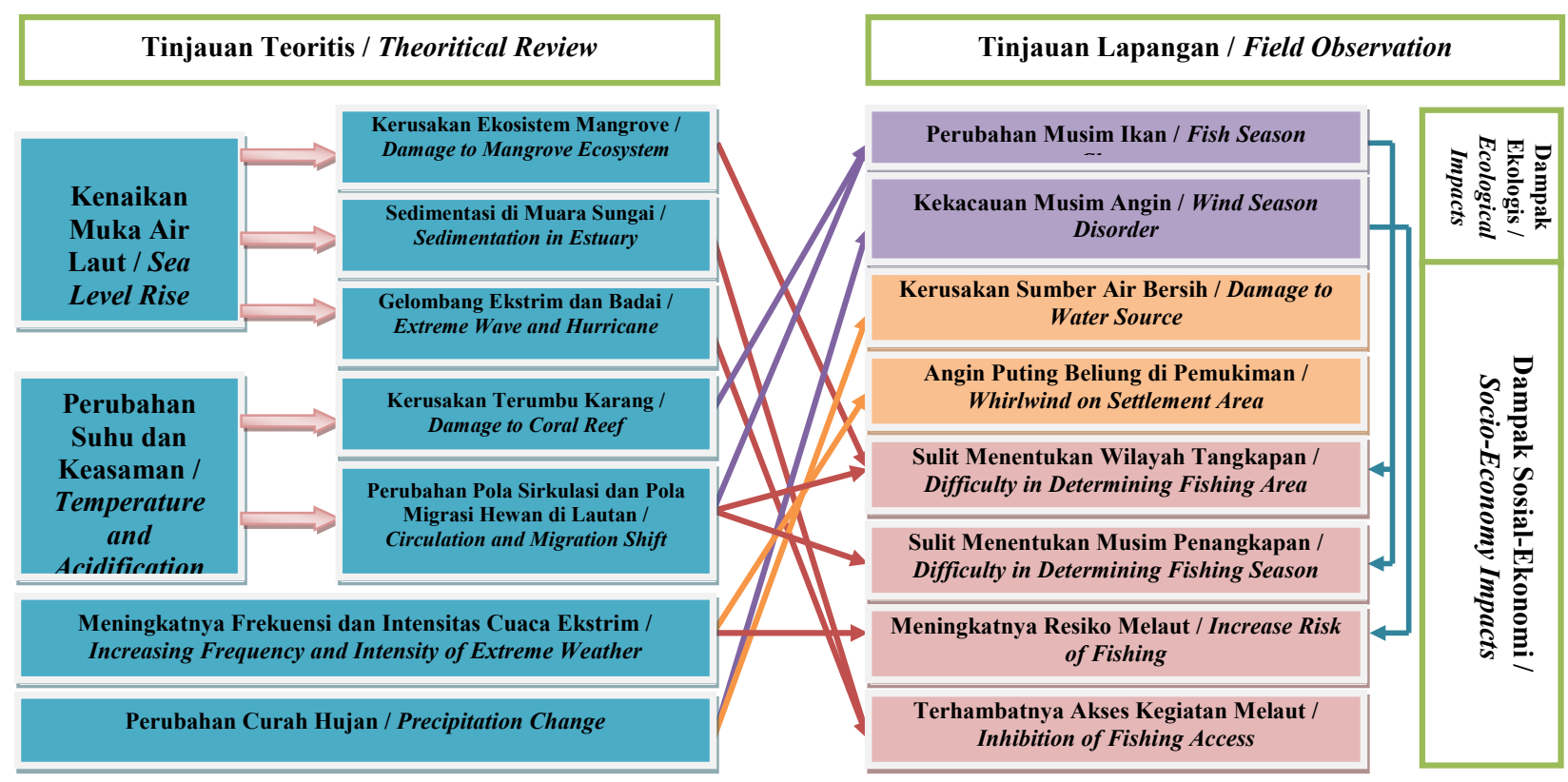

Keterangan / Information:

$\rightarrow$ Hubungan Pengaruh / Influence Correlation

Gambar 5. Dampak Perubahan Iklim pada Kegiatan Penangkapan Ikan dan Kehidupan Sosial-Ekonomi Nelayan, Berdasarkan Persepsi Nelayan di Ciawitali yang Disistematisasi oleh Peneliti.

Figure 5. Impacts of Climate Change to Fishing Activity and Socio-Economy of Fishers, Base on Ciawitali's Fishers Perception which was Systematized by Researcher.

Sumber: Data pimer diolah (2010) / Source: Primary data, processed (2010) 
Selain kepiting bakau, komoditas lain yang dapat diperoleh dari wilayah mangrove adalah ikan belanak serta kerang atau totok. Kerang totok ini adalah sejenis kerang hidup di wilayah pasang surut serta sekitar mangrove. Para istri nelayan seringkali mencari kerang ini untuk dikonsumsi ataupun diolah menjadi sate kerang kemudian dijual. Kelimpahan kerang totok di wilayah mangrove Ciawitali masih cukup tinggi. Pengolahan kerang ini dapat menjadi alternatif tambahan pendapatan bagi keluarga nelayan ketika nelayan mengalami kesulitan melaut.

\section{3). Adaptasi Alokasi Sumber daya Manusia dalam} Rumah Tangga

\section{a). Optimalisasi Tenaga Kerja Rumah Tangga}

Ketika musim ikan sedang tidak menentu dan frekuensi melaut nelayan semakin berkurang, anak-anak nelayan seringkali mencari tangkapan di wilayah mangrove, baik bersama nelayan (ayahnya) ataupun bersama anak-anak nelayan lainnya. Para istri nelayan juga berperan dalam menyelamatkan ekonomi keluarga dengan melakukan usaha-usaha lainnya seperti pengolahan totok. Selain itu, ketika musim paceklik berkepanjangan dimana nelayan mulai melakukan pekerjaan sambilan sebagai buruh tani, para istri nelayan juga biasanya ikut melakukan pekerjaan yang sama bersama suami demi menambah penghasilan yang didapatkan. Optimalisasi tenaga kerja rumah tangga yang paling menghasilkan biasanya diperoleh jika salah satu anggota keluarga mulai melakukan migrasi, mencari pekerjaan ke kota atau menjadi TKI (Tenaga Kerja Indonesia) ke luar negeri. Beberapa istri nelayan mengaku sempat menjadi TKI di Arab Saudi demi menambah penghasilan keluarga. Keluarga yang salah satu anggotanya pernah menjadi TKI biasanya terlihat dari bentuk rumah yang lebih baik dibandingkan dengan rumah-rumah nelayan pada umumnya.

\section{b). Pola Nafkah Ganda Tani-Nelayan}

Lahan pertanian yang cukup luas di wilayah Ciawitali mendorong pola adaptasi nelayan ke arah pertanian. Perubahan iklim menyebabkan meningkatnya resiko melaut sehingga memaksa nelayan untuk mencari alternatif sumber nafkah di daratan. Salah satu yang paling dominan adalah buruh tani. Berdasarkan data dari Risk Assesment IPPHTI (Ikatan Petani Pengendalian
Hama Terpadu Indonesia) pada tahun 2009, terdapat 125,2 hektar lahan pertanian padi sawah di Dusun Ciawitali. Hal ini merupakan salah satu peluang nafkah yang biasanya dimanfaatkan oleh nelayan dengan menjual jasa sebagai buruh tani. Salah seorang nelayan yang melakukan adaptasi sebagai buruh tani, ST (29 tahun) mengungkapkan pengalamannya sebagai berikut:

\section{"Jika tiba musim paceklik di laut dan musim panen di sawah, saya dan (nelayan) yang lainnya seringkali bekerja memanen padi di sawah. Pendapatan yang diperoleh cukup lumayan, dari $60 \mathrm{~kg}$ padi yang dipanen, kita mendapat $10 \mathrm{~kg}$ padi. Sawah yang dikerjakan ini biasanya milik para petani di Dusun Pamotan."}

Selain sebagai buruh pada lahan padi sawah, sebagian nelayan juga menggarap lahan miliknya sendiri. Lahan ini biasanya adalah kebun. Salah satu yang cukup potensial adalah kebun jati dan sengon. Sebagian nelayan sejak dahulu telah menanam jati dan sengon pada lahan yang dimilikinya. Meskipun tidak dapat dikategorikan sebagai bentuk adaptasi, namun pemanfaatan jati dan sengon pada kebun nelayan juga turut berkontribusi dalam menyelamatkan perekonomian nelayan Ciawitali selama musim paceklik.

\section{c). Pola Nafkah Ganda Jasa Pengangkutan}

Perahu, bagi kebanyakan nelayan merupakan harta sekaligus modal satu-satunya yang dapat diandalkan untuk melakukan usaha-usaha ekonomi. Ketika musim paceklik tiba, nelayan yang memiliki perahu menggunakan perahu mereka sebagai jasa pengangkutan. Perahu ini seringkali disewa sebagai sarana pengangkut hasil kayu yang ditebang di hutan masyarakat sekitar muara sungai dan tebing di tepian pantai. Berbagai komoditas pertanian yang dihasilkan dari Pulau Nusa Kambangan juga seringkali disebrangkan menuju pelabuhan Dusun Majingklak, Desa Pamotan menggunakan perahu nelayan, sebagaimana diungkapkan pula oleh salah seorang nelayan, SM (40 tahun) pada bulan Juni 2010 :

"Sudah hampir tiga bulan perahu saya dan banyak nelayan lain yang tidak turun ke laut mencari ikan. Cuacanya sangat buruk, ikan-ikan juga semakin jarang. Kalau sudah seperti ini pekerjaan apa saja asal halal pasti ditekuni. Apa saja, mengangkut pisang dari nusa kambangan 
ke majingklak pun jadi. Setidaknya anak-istri masih bisa makan..."

d). Adaptasi Melalui Keluar dari Kegiatan Perikanan (Escaping from Fisheries)

Kondisi ekosistem pesisir Ciawitali yang semakin memprihatinkan dari hari ke hari, penghasilan dari laut yang semakin tidak mencukupi kebutuhan ekonomi keluarga, serta keterbatasan sarana yang dimiliki menyebabkan sebagian nelayan memutuskan untuk tidak lagi bekerja sebagai nelayan dan mencari pekerjaan baru. Terdapat dua pekerjaan yang biasanya menjadi tujuan alih profesi ini, yaitu buruh pabrik dan petani. Pekerjaan sebagai buruh ini diminati karena adanya kepastian penghasilan yang diperoleh. Kedua adalah petani. Nelayan cenderung memilih untuk berganti profesi menjadi petani berdasarkan ketersediaan sumber daya yang ada, dimana Dusun Ciawitali merupakan wilayah dengan lahan pertanian yang cukup luas.

\section{Faktor-faktor yang Memengaruhi Pilihan Adaptasi dan Strategi Ekonomi Nelayan}

Pilihan strategi ekonomi dan adaptasi nelayan dipengaruhi oleh berbagai faktor dapat dilihat pada karakteristik individu nelayan pelaku adaptasi/strategi tersebut. Karakteristik ini diantaranya adalah klasifikasi nelayan, luasnya jejaring sosial nelayan tersebut, kepemilikan sarana produksi perikanan seperti perahu dan alat tangkap lainnya, status sosial nelayan, banyaknya jumlah anggota keluarga nelayan serta kedekatan nelayan tersebut dengan suatu budaya pekerjaan.

Hubungan antara pilihan strategi dan adaptasi yang dilakukan oleh nelayan dengan faktor yang memengaruhinya, berdasarkan observasi peneliti, dapat dilihat dalam Tabel 2.

Tabel 2. Jenis Adaptasi dan Strategi Ekonomi Nelayan, Serta Faktor yang Mempengaruhi.

Table 2. Types of Adaptation and Economic Strategy of Fisher and the Influencing Factors.

\begin{tabular}{|c|c|c|c|}
\hline No. & $\begin{array}{c}\text { Jenis Adaptasi dan } \\
\text { Strategi Ekonomi / } \\
\text { Types of Adaptation and } \\
\text { Economic Strategy }\end{array}$ & $\begin{array}{c}\text { Uraian I } \\
\text { Description }\end{array}$ & $\begin{array}{c}\text { Karakteristik Nelayan I } \\
\text { Characteristic of the Fishers }\end{array}$ \\
\hline 1. & $\begin{array}{l}\text { Adaptasi Iklim / Climate } \\
\text { Adaptation }\end{array}$ & $\begin{array}{l}\text { Melakukan perpindahan wilayah } \\
\text { tangkapan dengan memanfaatkan } \\
\text { informasi mengenai musim ikan } \\
\text { di wilayah lain / Move to other } \\
\text { catchment area by utilizing } \\
\text { information about fish season in } \\
\text { other area }\end{array}$ & $\begin{array}{l}\text { Nelayan penuh dengan kapasitas dan } \\
\text { kepemilikan sarana produksi yang lebih } \\
\text { memadai. Memiliki jejaring sosial yang luas } \\
\text { antar nelayan di berbagai tempat / Fulltime } \\
\text { fishers with capability and ownership of } \\
\text { adequate fishing facilities }\end{array}$ \\
\hline 2. & $\begin{array}{l}\text { Adaptasi Sumberdaya } \\
\text { Pesisir / Coastal } \\
\text { Resource Adaptation }\end{array}$ & $\begin{array}{l}\text { Pencarian hasil tangkapan tanpa } \\
\text { harus pergi ke laut lepas / Looking } \\
\text { for other fishing commodity without } \\
\text { go to the sea }\end{array}$ & $\begin{array}{l}\text { Nelayan penuh yang memiliki sarana } \\
\text { produksi cukup memadai, namun } \\
\text { cenderung kurang memiliki jejaring sosial } \\
\text { yang luas / Fulltime fishers with sufficient } \\
\text { fishing facilities, but tend to have less social } \\
\text { network }\end{array}$ \\
\hline \multirow[t]{3}{*}{3.} & $\begin{array}{l}\text { Adaptasi Alokasi } \\
\text { Sumberdaya Manusia } \\
\text { dalam Rumah Tangga } \\
\text { IAdaptation human } \\
\text { resource allocation within } \\
\text { household: }\end{array}$ & & \\
\hline & $\begin{array}{l}\text { a. Optimalisasi Tenaga } \\
\text { Kerja Rumah Tangga / } \\
\text { Optimalization of Labor } \\
\text { in The Family }\end{array}$ & $\begin{array}{l}\text { Melibatkan peran dari anggota } \\
\text { keluarga dalam perekonomian } \\
\text { rumah tangga / Involves the role } \\
\text { of family members in the } \\
\text { household economy }\end{array}$ & $\begin{array}{l}\text { Keluarga nelayan dengan jumlah anggota } \\
\text { keluarga yang tinggi dan cenderung jejaring } \\
\text { sosial yang luas / Household with a high } \\
\text { number of family member and tend to have } \\
\text { wider social network }\end{array}$ \\
\hline & $\begin{array}{l}\text { b. Nafkah Ganda: Tani- } \\
\text { Nelayan / Multiple } \\
\text { Livelihood: Farmer- } \\
\text { Fisher }\end{array}$ & $\begin{array}{l}\text { Bekerja sebagai buruh tani selama } \\
\text { paceklik atau mencari sumber } \\
\text { pendapatan lain dari kegiatan } \\
\text { berkebun / Work as a peasant } \\
\text { during the bad season or find } \\
\text { another source of income from } \\
\text { gardening/farming activities }\end{array}$ & $\begin{array}{l}\text { Nelayan yang dekat dengan budaya } \\
\text { pertanian, memiliki kerabat petani atau } \\
\text { dahulu merupakan seorang petani / Fishers } \\
\text { with a high connection to farming cultures, } \\
\text { have relatives farmer, or a fishers who was } \\
\text { a famer previously }\end{array}$ \\
\hline
\end{tabular}


Lanjutan Tabel 2/Continues Table 2

\begin{tabular}{|c|c|c|c|}
\hline No. & $\begin{array}{c}\text { Jenis Adaptasi dan } \\
\text { Strategi Ekonomi / } \\
\text { Types of Adaptation and } \\
\text { Economic Strategy }\end{array}$ & $\begin{array}{c}\text { Uraian I } \\
\text { Description }\end{array}$ & $\begin{array}{c}\text { Karakteristik Nelayan I } \\
\text { Characteristic of the Fishers }\end{array}$ \\
\hline \multirow{4}{*}{5.} & $\begin{array}{l}\text { C. Nafkah Ganda: Jasa } \\
\text { Pengangkutan / } \\
\text { Multiple Livelihood: } \\
\text { Transfer Service }\end{array}$ & $\begin{array}{l}\text { Memanfaatkan perahu yang } \\
\text { dimilikinya untuk mengangkut } \\
\text { berbagai komoditas dari pulau } \\
\text { nusa kambangan atau daerah- } \\
\text { daerah di tepi laut. / Utilizing their } \\
\text { boat to transfer various commodity } \\
\text { from Nusa Kambangan island, or } \\
\text { other area along the waterfront }\end{array}$ & $\begin{array}{l}\text { Nelayan dengan status sosial yang } \\
\text { cenderung lebih rendah, namun memiliki } \\
\text { sarana produksi yang memadai / Fishers } \\
\text { with lower social status but have sufficient } \\
\text { fishing facility }\end{array}$ \\
\hline & $\begin{array}{l}\text { Keluar dari Kegiatan } \\
\text { Perikanan / escaping } \\
\text { from fisheries: }\end{array}$ & & \\
\hline & a. Buruh / Labor & $\begin{array}{l}\text { Meninggalkan pekerjaan sebagai } \\
\text { nelayan dan beralih menjadi buruh } \\
\text { tetap / Leaving their job as a fisher } \\
\text { and turn into permanent labor }\end{array}$ & $\begin{array}{l}\text { Nelayan dengan status sosial yang rendah, } \\
\text { dengan kepemilikan sarana produksi yang } \\
\text { rendah pula / Fishers with lower social } \\
\text { status, without an adequate fishing facility }\end{array}$ \\
\hline & b. Petani / Farmer & $\begin{array}{l}\text { Meninggalkan pekerjaan sebagai } \\
\text { nelayan dan beralih menjadi petani } \\
\text { sepenuhnya / Leaving their job } \\
\text { as a fisher and turn into fulltime } \\
\text { farmer }\end{array}$ & $\begin{array}{l}\text { Nelayan yang sejak dahulu merupakan } \\
\text { petani (tani-nelayan) serta nelayan yang } \\
\text { dekat dengan budaya pertanian ataupun } \\
\text { memiliki lahan pertanian / Halftime fishers } \\
\text { who works as farmers since a long time } \\
\text { ago, fishers with a high connection to } \\
\text { farming cultures, and fishers who own an } \\
\text { agriculture land }\end{array}$ \\
\hline
\end{tabular}

Sumber: Data primer diolah (2010) / Source: Primary data, processed (2010)

\section{KESIMPULAN DAN IMPLIKASI KEBIJAKAN}

\section{Kesimpulan}

Perubahan iklim yang terjadi mepengaruhi aktivitas penangkapan ikan yang dilakukan oleh nelayan akibat terjadinya perubahan ekologi yang meliputi perubahan musim ikan dan kekacauan musim angin. Dampaknya adalah menurunnya hasil tangkapan yang disebabkan oleh sulitnya menentukan wilayah tangkapan, sulitnya menentukan musim penangkapan ikan, meningkatnya resiko melaut dan terhambatnya akses kegiatan melaut.

Adaptasi dan strategi ekonomi yang dilakukan oleh nelayan dalam menghadapi permasalah perubahan iklim ini didominasi oleh pola-pola adaptasi yang sifatnya reaktif. Hal ini terjadi karena nelayan Ciawitali hingga sejauh ini masih merupakan nelayan tradisional dengan akses teknologi serta informasi yang relatif terbatas sehingga bentuk adaptasi yang lebih antisipatif belum ada dan belum diketahui oleh masyarakat. Bentuk adaptasi yang telah dilakukan antara lain yaitu:

1. Adaptasi iklim berupa mengejar musim ikan ke wilayah lain.

2. Adaptasi sumber daya pesisir dengan mencari hasil tangkapan di wilayah mangrove.

3. Adaptasi alokasi sumber daya manusia dalam rumah tangga yang meliputi optimalisasi tenaga kerja rumah tangga, pola nafkah ganda tani-nelayan, serta jasa pengangkutan menggunakan perahu nelayan.

4. Adaptasi melalui keluar dari kegiatan perikanan (escaping from fisheries) dengan cara beralih profesi. 


\section{Implikasi Kebijakan}

Adapun saran yang dapat direkomendasikan dari hasil penelitian ini adalah pengembangan sistem informasi prakiraan cuaca untuk nelayan dan penguatan kapasitas adaptasi untuk mendukung bentuk-bentuk adaptasi perubahan iklim yang sifatnya antisipatif. Wujud konkrit dari penguatan kapasitas adaptasi nelayan terhadap perubahan iklim ini antara lain:

1. Pengembangan pola nafkah ganda bagi nelayan,

2. Teknologi yang memadai untuk mencari ikan di tengah cuaca yang buruk,

3. Diversifikasi alat tangkap untuk mengantisipasi variasi musim.

\section{DAFTAR PUSTAKA}

Chen, CTA. 2008. "Effects of Climate Change on Marine Ecosystem," Fisheries for Global Welfare and Environment: 5th World Fisheries Congress. K. Tsukamoto, T. Kawamura, T. Takeuchi, T. D. Beard, Jr. and M. J. Kaiser. eds. Tokyo: TERRAPUB.

Diposaptono, S., Budiman, dan F. Agung. 2009. Menyiasati Perubahan Iklim di Wilayah Pesisir dan Pulau-Pulau Kecil. Bogor: PT. Sarana Komunikasi Utama
Miles, M.B dan M.A. Huberman 2009. Manajemen Data dan Metode Analisis, in: Denzin, Norman K. and Yvonna S. Lincoln. (Eds). Handbook of Qualitative Research pp.591-612. Penerj. Dariyatno, et al. Yogyakarta: Pustaka Pelajar.

IPCC. 2007. Climate Change 2007: Impacts, Adaptation and Vulnerability. Cambridge: Cambridge University Press.

Murdiyarso, D. 2007. Protokol Kyoto: Implikasinya bagi Negara Berkembang. Jakarta: Kompas.

Odum, E. P. 1994. Dasar-dasar Ekologi, edisi ketiga (terjemahan). Yogyakarta: Gadjahmada University Press.

Satria, A. 2009. Pesisir dan Laut Untuk Rakyat. Bogor: IPB Press.

Stake, R. E. 2009. "Studi Kasus," Handbook of Qualitative Research. Norman K. Denzin dan Yvonna S. Lincoln, Eds. Yogyakarta: Pustaka Pelajar.

Supriharyono. 2007. Pengenalan Ekosistem Terumbu Karang. Jakarta: Djambatan.

Tebtebba. 2008. Panduan Tentang Perubahan Iklim dan Masyarakat Adat (terjemahan). Philippines: Tebtebba Foundation

UNEP. 2009. Climate Change Science Compendium. United Nation Environment Programme. http://www.unep.org/pdf/ccScienceCompendium2009. (Diakses pada 28 Januari 2010). 